\title{
Mycoremediation of Textile Effluent: A Toxicological Evaluation and its Possible Correlation with COD
}

\section{Geetanjali Rajhans}

Siksha O Anusandhan University

Adyasa Barik

Siksha O Anusandhan University

\section{Sudip Sen}

Biostadt India Ltd.

\section{Amrita Masanta}

Siksha O Anusandhan University

Naresh Sahoo

Siksha O Anusandhan University

Sangeeta Raut ( $\nabla$ research.sangeeta@gmail.com )

Siksha O Anusandhan University

\section{Research Article}

Keywords: BOD, COD, Color, LC-MS, Toxicity, XRD

Posted Date: March 26th, 2021

DOI: https://doi.org/10.21203/rs.3.rs-356935/v1

License: (c) (i) This work is licensed under a Creative Commons Attribution 4.0 International License. Read Full License

Version of Record: A version of this preprint was published at Scientific Reports on August 5th, 2021. See the published version at https://doi.org/10.1038/s41598-021-94666-8. 


\title{
Mycoremediation of textile effluent: A toxicological evaluation and its possible correlation with COD
}

\author{
Geetanjali Rajhans ${ }^{\mathrm{a}}$, Adyasa Barik ${ }^{\mathrm{a}}$, Sudip Kumar Sen ${ }^{\mathrm{b}}$, Amrita Masanta $^{\mathrm{a}}$, Naresh Kumar Sahoo ${ }^{\mathrm{c}}$, Sangeeta Raut ${ }^{\mathrm{a}}$ \\ ${ }^{a}$ Center for Biotechnology, School of Pharmaceutical Sciences, Siksha O Anusandhan (Deemed to be University), \\ Bhubaneswar -751003, Odisha, India \\ ${ }^{b}$ Biostadt India Limited, Waluj, Aurangabad-431136, Maharashtra, India \\ ${ }^{c}$ Department of Chemistry, ITER, Siksha O Anusandhan (Deemed to be University), Bhubaneswar -751003, Odisha, \\ India
}

\begin{abstract}
*Corresponding author: Center for Biotechnology, School of Pharmaceutical Sciences, Siksha O Anusandhan
\end{abstract} (Deemed to be University), Bhubaneswar-751003, Odisha, India Email address: research.sangeeta@gmail.com (S. Raut), 9438450789

\begin{abstract}
Globally, textile industries are one of the major sectors releasing dye pollutants. This is the first report on the positive correlation between toxicity and COD of textile effluent along with the proposed pathway for enzymatic degradation of acid orange 10 using Geotrichum candidum within a very short stretch of time (18h). Removal efficiency of this mycoremedial approach after $18 \mathrm{~h}$ in terms of color, dye concentration as well as reduction of chemical oxygen demand (COD) and biological oxygen demand (BOD) in the treated effluent reached to 89\%, 87\%, 98.5\% and 96.3\% respectively. FT-IR analysis of the treated effluent confirmed biodegradation. The LC-MS analysis showed the degradation of acid orange 10, which was confirmed by the formation of two biodegradation products, 7-oxo-8-iminonapthalene-1,3-disulfonate and nitrosobenzene, which subsequently undergoes stepwise hydrogenation and dehydration to form aniline via phenyl hydroxyl amine as intermediate. The X-ray diffraction (XRD) studies showed that heavy metals content in the treated effluent has reduced along with decrease in \% crystallinity, indicating biodegradation. The connection between toxicity and COD was also inveterated using Pearson's correlation coefficient. Further the toxicological studies indicated the toxicity of raw textile effluent and relatively lower toxic nature of metabolites generated after biodegradation by G. candidum.
\end{abstract}

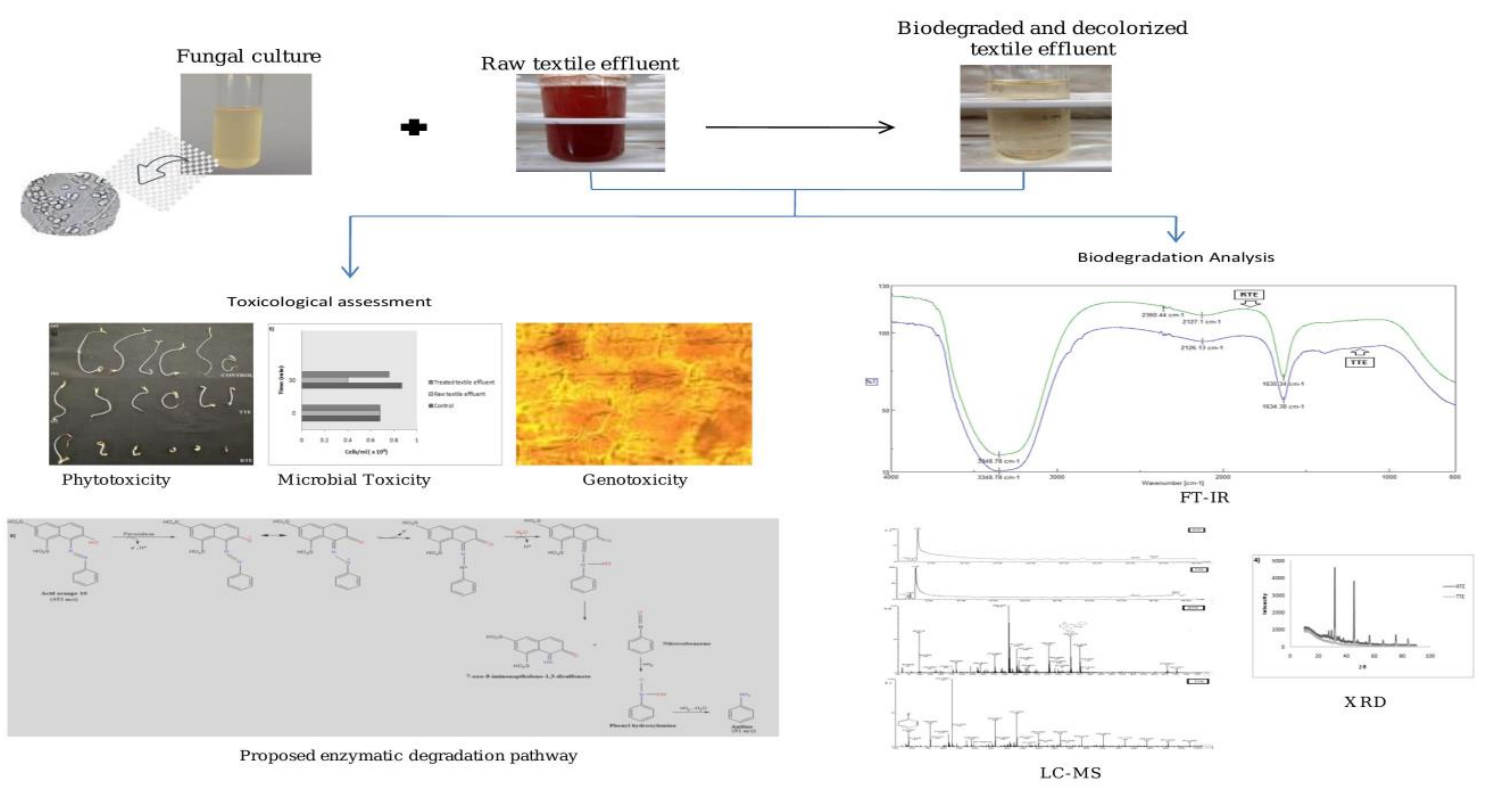


Keywords: BOD, COD, Color, LC-MS, Toxicity, XRD

\section{Declarations}

Funding- This study has been funded by the Department of Science and Technology (DST/SSTP/Odisha/443) and is greatly acknowledged. mandatory)

Ethics approval (include appropriate approvals or waivers) - Not applicable

Consent to participate (include appropriate statements) - Not applicable

Consent for publication (include appropriate statements)- The authors have their consent for the publication of this manuscript if accepted

\section{Acknowledgments}

This study has been funded by the Department of Science and Technology (DST/SSTP/Odisha/443) and is greatly acknowledged. We are grateful to the Center for Biotechnology, Siksha O Anusandhanhan (Deemed to be University), Bhubaneswar, for their support and encouragement. We also greatly acknowledge SAIF Chandigarh for their support in LC-MS analysis.

\section{Introduction}

Urbanization and industrialization have paved the path for development of the many industries, including the textile industries. Clothing and textiles, after agriculture, is the basic requirement of human being. While the textile industry contributes worldwide economically, the environmental effects are due to high volumes of water use and the diversity and quantities of chemicals that are used in all manufacturing phases of textiles. The untreated effluent when disposed in the water bodies seriously impacted the people in the area (Agrawal and Verma 2019). Rivers and drainage bodies get loaded with precarious textile effluents that impact on the water quality, the aquatic organisms and human life (Kumar et al. 2013, 2014, 2015a, b; Singh and Balomajumder 2016; Mishra et al. 2016). The diverse sort of dyes and chemicals used in textile manufacturing makes textile effluents very complex in terms of chemical compositions. According to previous records, in addition to dyes and its auxiliaries over 8000 chemicals are added such as several acids, salts, surfactants, metals, oxidizing and reducing agents (Reddy and Osborne 2020). These 
recalcitrants in untreated effluents are both harmful to marine and terrestrial organisms and have prolonged effects on health (Hamidi et al., 2014).

To assess the performance of wastewater treatment facilities, the influent and treated water samples after each 51 treatment phase (physical, chemical and biological) should be tracked. In general, microbial degradation is known to be a safe, natural, inexpensive and effective pollutant removal technique in the world (Mishra et al. 2016; Singh et al. 2017, 2018; Kumar et al. 2017). The eco-friendliness and low cost of biological technology has in particular gained significant attention (Maljaei et al. 2009). However, bacteria typically contribute to the breakdown of textile dyes creating and accumulating more intractable or hazardous aromatic amine substances that restrict their comprehensive applications to azo dye wastewater treatment plants (Davies et al. 2006). Enhanced techniques are evidently the pre-condition for accelerated elimination of azo dyes, because any residual contaminants should be removed completely. Fungi have been investigated, especially those secreting non-specific oxidases which eventually lead to the azo dyes mineralization into $\mathrm{CO}_{2}$ (Wanderley et al. 2018). Fungal degradation (Mycoremediation) also leads to complete decoloration and detoxification, which prevents sludge removal and secondary contamination issues.

Majority of studies based on toxicity assessments could be done with bioassays using all forms of harmful compounds found in textile effluent and may well be utilized to evaluate the effect of unidentified compounds which cause detrimental, additive and synergistic effects (Ma et al. 2016; Yu et al. 2014).

Geotrichum sp. out of the few fungi have been observed for degradation of large quantity of artificial colors and molasses (Kim and Shoda 1998, 1999; Chen and Zhao 2008; Shintani and Shoda 2013). Since, Geotrichum sp have not been explored much, therefore it is being used in the current study for the biodegradation and detoxification of textile effluent. The analysis of conventional parameters of textile effluent (before and after mycoremediation) and the inter-relationship between toxicity and COD have been carried out in this study. In an attempt to validate the non-toxicity of treated effluent, the biodegradation analysis such as FT-IR, LC-MS and XRD have been conducted. Furthermore, bioassays such as genotoxicity, phytotoxicity and microbial toxicity assays have also been carried out so that the toxicity level of raw and treated textile effluent can be assessed.

\section{Materials and Methods}

\subsection{Collection of samples}

Samples of textile dyeing effluent have been obtained from a nearby textile factory in Khurda, India. During regular operations, factory workers sampled $100 \mathrm{~mL}$ of wastewater every two hours to ensure that the study involves variability in substances.

\subsection{Microbial culture conditions}

This work utilizes Geotrichum candidum, a ubiquitous fungus belonging to Dipodoascaceae family. It was grown at $35^{\circ} \mathrm{C}$ on Potato Dextrose Agar plates (PDA) $(\mathrm{pH}-5.6 \pm 0.2)$. Pure fungal culture was inoculated in 3 percent malt extract broth after 24 hours to maintain the strain and cultured at $35^{\circ} \mathrm{C}, 100 \mathrm{rpm}$. Using DP media (dextrose and peptone in ratio of 2:3) at $35^{\circ} \mathrm{C}$ and $100 \mathrm{rpm}$, the optimum fungal growth was achieved (Rajhans et al. 2019).

\subsection{Analysis of conventional indicators of textile effluent}

In this part of the analysis, the G. candidum culture was used to biodegrade the textile effluent. A conical flask containing raw textile effluent $(25 \mathrm{ml})$ was inoculated with fungal culture $(5 \%, \mathrm{v} / \mathrm{v})$, followed by incubation at $35^{\circ} \mathrm{C}$, $100 \mathrm{rpm}$ (Rajhans et al. 2020). At regular intervals, aliquots were obtained from the flask and then centrifuged $(10,000 \times \mathrm{g})$ for $10 \mathrm{~min}$. Thereafter, the conventional indicators for raw and treated effluent such as, COD 
122

(Chemical Oxygen Demand), BOD (Biological Oxygen Demand), color and concentration were assessed following the Standards Methods (APHA 2017). COD concentrations were measured using the potassium dichromate method; Pt-Co color scale was used to measure color. Dye concentration of the sample was determined using colorimeter (Systonic, S-912). Every experiment has been carried out in triplicates and standard deviation has been presented with the average data.

The following equation (Eq. (1)) was used to quantify degradation as a percentage reduction of COD:

$$
\% \mathrm{COD}_{\text {reduction }}=\frac{\mathrm{COD}_{\text {initial }}-\mathrm{COD}_{\mathrm{t}}}{\mathrm{COD}_{\text {initial }}} \times 100
$$

COD initial:- initial value of COD

COD $:$ :- value of COD at time ' $t$ ' (h)

\subsection{Growth kinetics}

The following equation (2) has been used to determine the specific growth rate of G. candidum.

$$
\ln \frac{x}{x_{o}}=\mu t
$$

$\mathrm{x}$ : biomass concentration $\left(\mathrm{g} \mathrm{L}^{-1}\right)$ at ' $\mathrm{t}$ ' time

$\mathrm{x}_{0}$ : initial biomass concentration $\left(\mathrm{g} \mathrm{L}^{-1}\right)$ at ' $\mathrm{t}_{0}$ ' time

$\mu$ : specific growth rate $\left(\mathrm{h}^{-1}\right)$.

The expression for growth yield $(\mathrm{Y})$ is

$$
\frac{d x}{d s}=Y
$$

The equation 3 can be rewritten as follows (Vijayalakshmidevi and Muthukumar 2015):

$$
x-x_{o}=Y\left(S_{o}-S\right)
$$

$\mathrm{S}_{\mathrm{o}}$ : initial substrate (COD) concentration $\left(\mathrm{mg} \mathrm{L}^{-1}\right)$

$\mathrm{S}$ : final substrate (COD) concentration $\left(\mathrm{mg} \mathrm{L}^{-1}\right)$

$\mathrm{x}$ : biomass concentration $\left(\mathrm{mg} \mathrm{L}^{-1}\right)$

$\mathrm{x}_{0}$ : initial biomass concentration $\left(\mathrm{mg} \mathrm{L}^{-1}\right)$

\subsection{Analytical studies}

The metabolites formed in textile effluent after decolorization and degradation were obtained by same volume with ethyl acetate. The extract was dried over anhydrous sodium sulfate and evaporated to dryness in a rotary evaporator. The resulting crystals were dissolved in small volumes of methanol (HPLC grade), and then used for analysis such as FT-IR (Fourier-transform infrared spectroscopy), LCMS (Liquid chromatography-mass spectrometry) and XRD (X-ray Diffraction).

The FTIR analysis of the effluent was performed with Attenuated total reflectance- Fourier transform infrared spectroscopy (ATR-FTIR, FT/IR-4600, JASCO, Japan). A drop from each sample was placed on a Zinc selenide ( $\mathrm{ZnSe})$ frame, and the spectra were documented with an average of 32 scans between the 4000 and $600 \mathrm{~cm}^{-1}$ spectral ranges.

The raw and treated samples were also analyzed using LC-MS (Waters Micromass Q-Tof Micro) and the flow rate and temperature were maintained at $0.2 \mathrm{ml} \mathrm{min}^{-1}$ and $35^{\circ} \mathrm{C}$, respectively. The running time was 41 minutes. Two 
different solvents with varying proportions, such as water with $0.1 \%$ formic acid and acetonitrile with $0.1 \%$ formic acid were used. The deuterium lamp (DL) temperature was set at $250^{\circ} \mathrm{C}$ with $\mathrm{m} / \mathrm{z}$ value $50-1000$ runs in the positive ion mode.

X-ray diffraction patterns before and after biodegradation of textile effluent were recorded using RIGAKUULTIMA IV, Japan diffractometer with monochromatic $\mathrm{CuK} \alpha$ radiation $(\lambda=1.5406)$ over the range of $10-90^{\circ}(2 \theta)$. The metals were identified with powder diffraction standard file (JCPDS, Joint Committee on Powder Diffraction Standards Newtown Square, Pennsylvania, USA).

\subsection{Toxicity study}

2.6.1. Phytotoxicity

The phytotoxicity analysis was performed using Phaseolus mungo (at room temperature) on both raw and treated effluent. Simultaneously, the control set was conducted using water. After 7 days, toxicity of the raw and treated effluent was evaluated by the length of radical, plumule and germination percentage. Mean with standard deviation for all results were presented.

\subsubsection{Microbial toxicity}

A short-term toxicity test of textile effluent before and after treatment was demonstrated by exposing the bacteria Escherichia coli (ATCC 443) to the textile effluent for $15 \mathrm{~min}$. Toxicity to E. coli was determined spectrophotometrically by evaluating the difference in the number of cells before and after treatment. All the tests were conducted in triplicate. The experiment with control set was also carried out.

\subsubsection{Genotoxicity Study}

The study of genotoxicity was carried out with Allium cepa. Both raw and treated textile effluent is used to treat the roots. The growths after $48 \mathrm{~h}$ of incubation at room temperature were examined (Jadhav et al. 2010). A light microscope (NikonH600L Eclipses LV100) was used to obtain mean values of root length, mitotic index (MI) and chromosomal aberrations in the cell. The experiment was conducted in triplicates and the mean \pm standard deviation values were accounted.

\subsection{Statistical analysis}

The toxicity test results for E. coli were expressed as $\mathrm{EC}_{50}$, which represented a $50 \%$ inhibition of $E$. coli growth caused by a percentage concentration of the textile effluent $(\mathrm{v} / \mathrm{v}) . \mathrm{EC}_{50}$ was evaluated via the linear interpolation method (Norberg-King 1993).

Linear Regression method is to fit concentration- inhibition data to a linear regression and then to calculate $\mathrm{EC}_{50}$ values by linear interpolation. Interpolation log method is according to Huber and Koella (1993) using the following formula, Eq.(5) to calculate $\mathrm{EC}_{50}$ value.

$$
\log \left(E C_{50}\right)=\log \left(x_{1}\right)+\frac{50 \%-y_{1}}{y_{2}-y_{1}} \times\left[\log \left(x_{2}\right)-\log \left(x_{1}\right)\right]
$$

Direct Interpolation method is similar to interpolation log method but without logarithmic transformation of concentrations. The equation Eq.(6) for $\mathrm{EC}_{50}$ calculation is according to (Alexander et al. 1999) as follows.

$$
E C_{50}=x_{1}+\frac{50 \%-y_{1}}{y_{2}-y_{1}}\left(x_{2}-x_{1}\right)
$$


$\mathrm{x}_{1}, \mathrm{x}_{2}$ : two conc. of the textile effluent;

$\mathrm{y}_{1}, \mathrm{y}_{2}$ : corresponding inhibitions $\left(\mathrm{y}_{1}<50 \% ; \mathrm{y}_{2}>50 \%\right)$.

$\%$ Inhibition can be calculated from the following formula (7)(Wang et al. 2010)

$$
\frac{A_{\text {control }}-A_{\text {sample }}}{A_{\text {control }}} \times 100
$$

After evaluation of $\mathrm{EC}_{50}$, the toxicity of all samples were expressed as toxic units, $\mathrm{TU}$ (unitless), as per equation (8) (Sprague 1970),

$$
T U_{50}=100 / E C_{50}
$$

The Pearson's correlation coefficient at the significance level of 0.05 was used to assess the correlation between toxicity and conventional indicators of the raw and treated textile effluent, and the impact of COD on toxicity was analyzed by means of linear regression. The significance level of the regression analysis $(p)$ and $R^{2}$ illustrated the extent of toxicity variance caused by COD.

\section{Results and Discussion}

\subsection{Conventional indicators of textile effluent}

The conventional indicators of raw and treated textile effluent have been listed in Table 1. It was evident that the raw textile effluent was high in COD and BOD concentrations (Yaseen and Scholz 2016), which was way much higher than the permitted levels (COD- less than $250 \mathrm{mg} / \mathrm{L}$ and BOD- less than $30 \mathrm{mg} / \mathrm{L}$ in India). Studies show that common components of dye effluents such as some acid dyes and ionic dyes could easily escape into the environment leading to elevating levels of COD, BOD and coloration of water bodies(Lee et al. 2013). After treatment, it was observed that G. candidum was able to remove COD (98.5\%), BOD (96.3\%), concentration $(87 \%)$, color $(89 \%)$ from the textile effluent in $18 \mathrm{~h}$, which meets the discharge standards. The high removal efficiency of $G$. candidum improved the quality of textile effluent in terms of COD, BOD and color. A recent study showed the reduction in COD, BOD and color of the textile effluent by $77.5 \%, 71.0 \%$ and $99.2 \%$ respectively in 24 hours after treatment with Aspergillus niger (Gurbuz et al. 2019). Yet another study showed that $91 \%, 88 \%$ and $68 \%$ reduction was recorded in the color intensity, $\mathrm{COD}$ and $\mathrm{BOD}$ of the textile wastewater, respectively, after treatment with Peyronellaea prosopidis (Bankole et al. 2018).

Table1. Conventional indicators in raw and treated textile effluent

\begin{tabular}{|l|c|c|c|}
\hline Indicators & Raw textile effluent & $\begin{array}{c}\text { Treated textile effluent } \\
\text { (after 18h) }\end{array}$ & $\begin{array}{c}\text { Removal (\%) } \\
\text { (after 18h) }\end{array}$ \\
\hline COD $(\mathbf{m g} / \mathbf{L})$ & $902.1 \pm 0.05$ & $13.20 \pm 0.05$ & $\mathbf{9 8 . 5}$ \\
\hline BOD (mg/L) & $180.42 \pm 0.02$ & $6.64 \pm 0.02$ & $\mathbf{9 6 . 3}$ \\
\hline Color (hazen units) & 35400 & 3894 & $\mathbf{8 9}$ \\
\hline Concentration of sample(ppm) & 3100 & 400 & $\mathbf{8 7}$ \\
\hline
\end{tabular}

\subsection{Growth Kinetics Studies}

The specific growth rate of $0.127 \mathrm{~h}^{-1}$ and yield coefficient of $2.64 \mathrm{mg}$ of dry weight of biomass/mg COD were 
extreme conditions of the effluent, reducing COD efficiently. The literatures reported the specific growth rate of $0.116 \mathrm{~h}-1$ and yield coefficient of $1.22 \mathrm{mg}$ of dry weight of biomass $/ \mathrm{mg}$ COD (Vijayalakshmidevi and Muthukumar 2015). Yet another report showed the specific growth rate varying from 0.001 to $0.003 \mathrm{~h}^{-1}$ and yield coefficient varying from 0.25 to $0.75 \mathrm{mg}$ of dry weight of biomass/mg COD (Bayram et al. 2017).

\subsection{Characterization of biodegraded textile effluent}

FT-IR: G. candidum-induced effluent biodegradation was established through FTIR spectral analyses (Fig. 1). The process of biodegradation is demonstrated either by loss of absorbance peaks or by the occurrence of new peaks (Chen et al. 2003; Sen et al. 2019). The FTIR spectrum of the untreated effluent represented the variable stretching vibrations of $\mathrm{C}=\mathrm{C}$ (alkenyl), $\mathrm{C}=\mathrm{C}$ (alkyne), $\mathrm{P}-\mathrm{H}$ (phosphine) and $\mathrm{N}-\mathrm{H}$ (amine) at $1635 \mathrm{~cm}^{-1}, 2127 \mathrm{~cm}^{-1}, 2360 \mathrm{~cm}^{-1}$ and $3348 \mathrm{~cm}^{-1}$ respectively. The biodegradation products obtained after $18 \mathrm{~h}$ of treatment showed disappearance of phosphine group and occurrence of a new peak at $530 \mathrm{~cm}^{-1}$, representing the occurrence of strong stretching vibration of $\mathrm{C}-\mathrm{Br}$ (alkyl bromide)(Fig. 1). The biodegradation of raw textile effluent by G. candidum was clearly established in this study. Previous studies have established that the biodegradation of textile dyes can be confirmed by FT-IR spectrum representing occurence of new peaks (Sen et al. 2019).

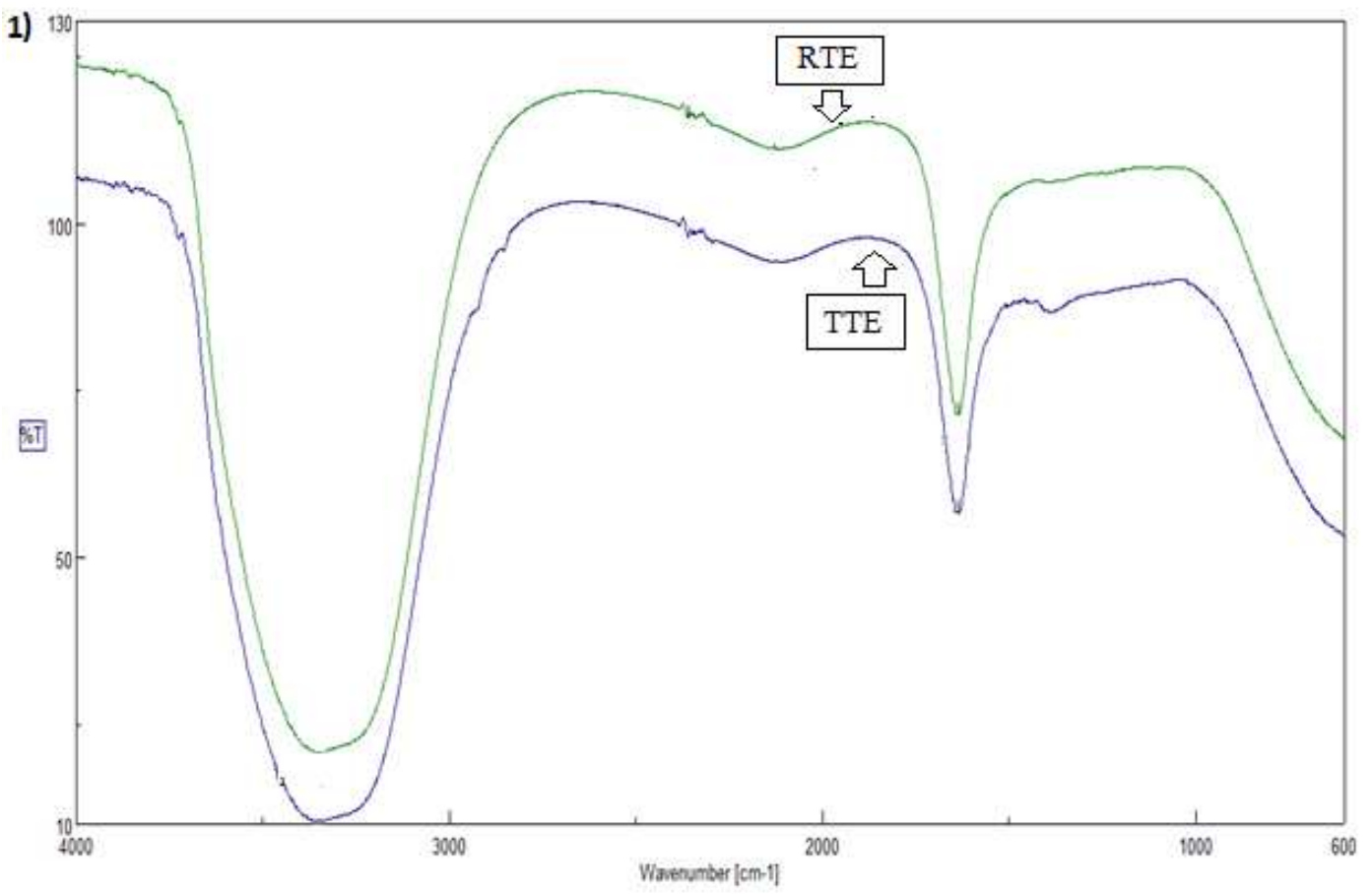

Fig.1 FT-IR spectral analyses of raw and treated textile effluent

LC-MS: In positive ion and full scanning mode, the textile dye effluent was analyzed from 100 to $1000 \mathrm{~m} / \mathrm{z}$. Several mass peaks of varying values have been observed with both raw and treated effluent (Fig. 2a). For the raw effluent, a mass peak at $453 \mathrm{~m} / \mathrm{z}$ (m.w. 452) was identical to that of an azo dye, acid orange 10 (Fig. 2b). Hence, it was evident that the acid orange 10 was a major dye component of the textile effluent used in this study. The identification of metabolites produced prior to biodegradation of effluent was carried out and the plausible biodegradation pathway based on the previous reports was predicted. (Chacko and Subramaniam 2011). The secretion and involvement of ligninolytic enzymes (laccase and lignin peroxidase) in the azo dye degradation process of $G$. candidum was evident from our previous study (Rajhans et al. 2020). The degradation of acid orange 10 by peroxidase leads to the formation of two biodegradation products such as 7-oxo-8-iminonapthalene-1,3-disulfonate 
272 and nitrosobenzene, which subsequently undergoes stepwise hydrogenation and dehydration to form aniline (m.w.

273 93, m/z 91)(Fig. 2c), via phenyl hydroxyl amine intermediate (as proposed by Mahata and co-workers (2014). The

274 degradation pathway has been predicted in Fig.3. Aniline was found in the treated effluent as a low molecular

275 weight compound, rendering it less toxic.
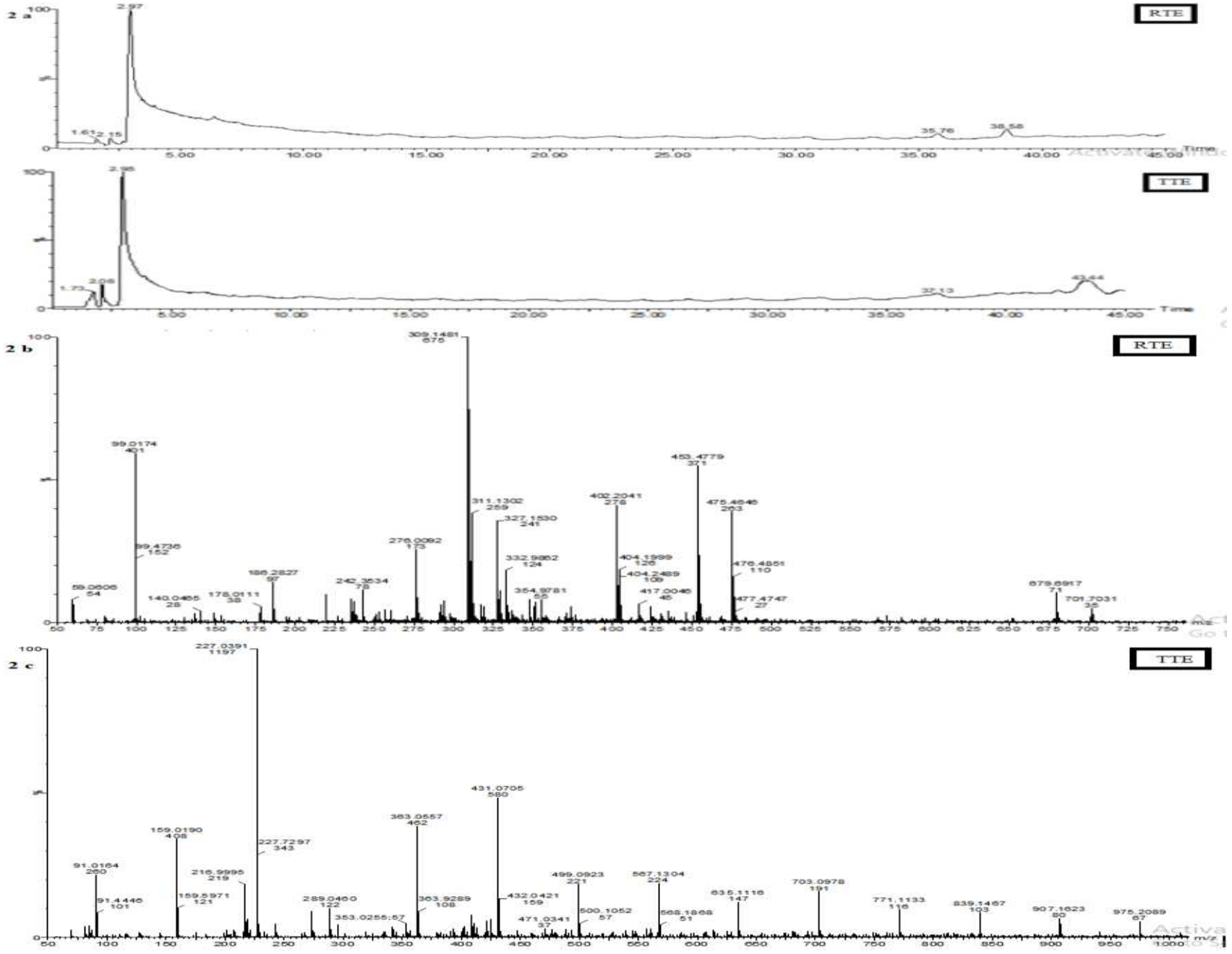

Fig.2 LC-MS analysis of raw and treated textile effluent
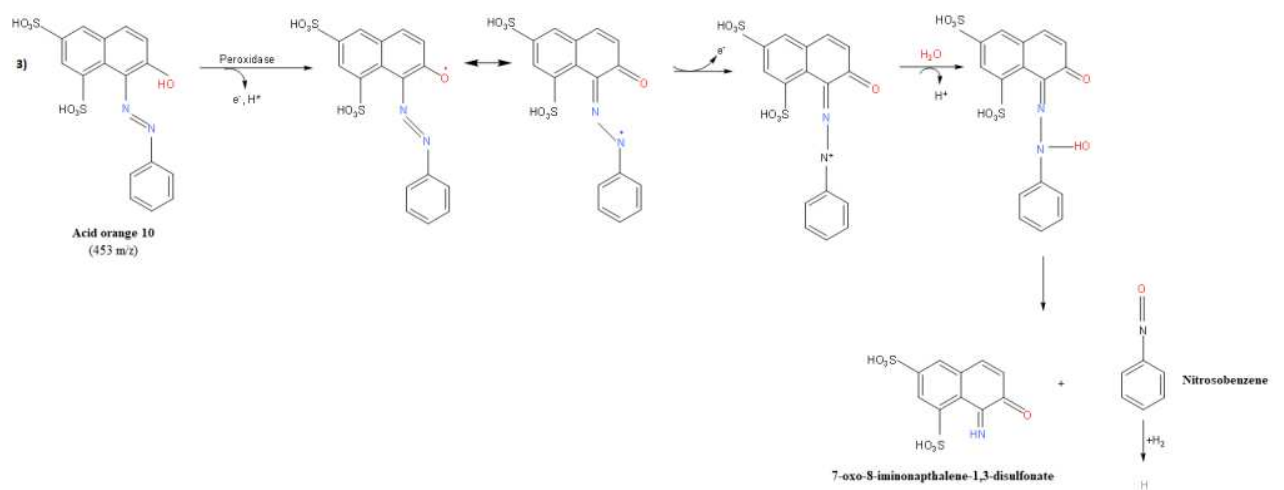
Fig.3 Proposed pathway for degradation of acid orange 10 dye by G. candidum

XRD: Heavy metal ions can be prevalent in textile effluent because of the metal-associated dyes and/or additional components used in the dyeing process. The X-ray spectra obtained for the dried samples of the untreated and treated effluent after $18 \mathrm{~h}$ treatment with $G$. candidum are shown in Fig. 4. This displayed various peaks that specifically indicated the presence of metals in raw effluent. The $2 \theta$ values of $32.36^{\circ}$ and $50.5^{\circ}$ showing the presence of major metals, such as lead and mercury respectively. The presence of these metals was confirmed using standard JCPDS reference code $(04-0686(\mathrm{~Pb})$ and 01-085-0211(Hg)). Subsequently, the X-ray spectra of treated effluent showed absence of $\mathrm{Pb}$ as well as the considerable decrease in the peak intensity for $\mathrm{Hg}$ indicating the decreased toxicity of the effluent (Fig. 4). A decrease in \% crystallinity was observed in the textile effluent after it was exposed to G. candidum, indicating the degradation of the effluent. Previous studies have demonstrated similar removal of the heavy metals from textile effluent (Vijayalakshmidevi and Muthukumar 2015). The presence of heavy metals in the effluent lead to numerous health hazards and sequential treatment would eliminate the heavy metals, and make the treated effluent more safe to discharge into the environment.

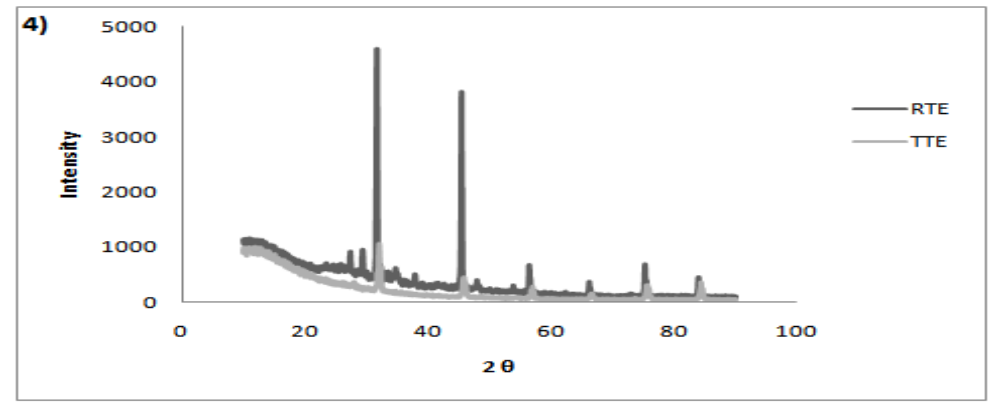

Fig.4 X-ray diffraction pattern of raw and treated textile effluent

\subsection{Toxicity evaluation}

\subsubsection{Phytotoxicity}

Agriculturally valuable seeds i.e. P. mungo were used for phytotoxicity assessment of raw and treated textile effluent. The analyzed parameters were germination percentage, plumule and radical length. The seeds treated with water were considered as positive control and the test samples were significantly compared with each other, a maximum germination of $100 \%$ was recorded in P. mungo with treated textile effluent indicating it as less phytotoxic. Seeds treated with raw textile effluent showed a minimal germination of 33\% (Fig. 5). Though the seeds exposed to raw textile effluent germinated, they couldn't grow further, exhibiting maximum phytotoxicity. The results shown in Table 2 indicated that the germination (\%) and length of plumule and radicle of $P$. mungo seeds were less with the untreated as compared to treated effluent. This study shows that the metabolites formed after effluent biodegradation are less harmful than the compound present in the raw textile effluent. It is evident that the seed germination and average plumula and radical development were unaffected by decolored textile effluent. Thus, the comprehensive results indicated that the textile effluent treated with G. candidum was not harmful to plant germination and growth Similar kind of phytotoxicity studies can be seen reported for several times in the literature. This ensures that treated effluent could be used for agriculture or recycled. 


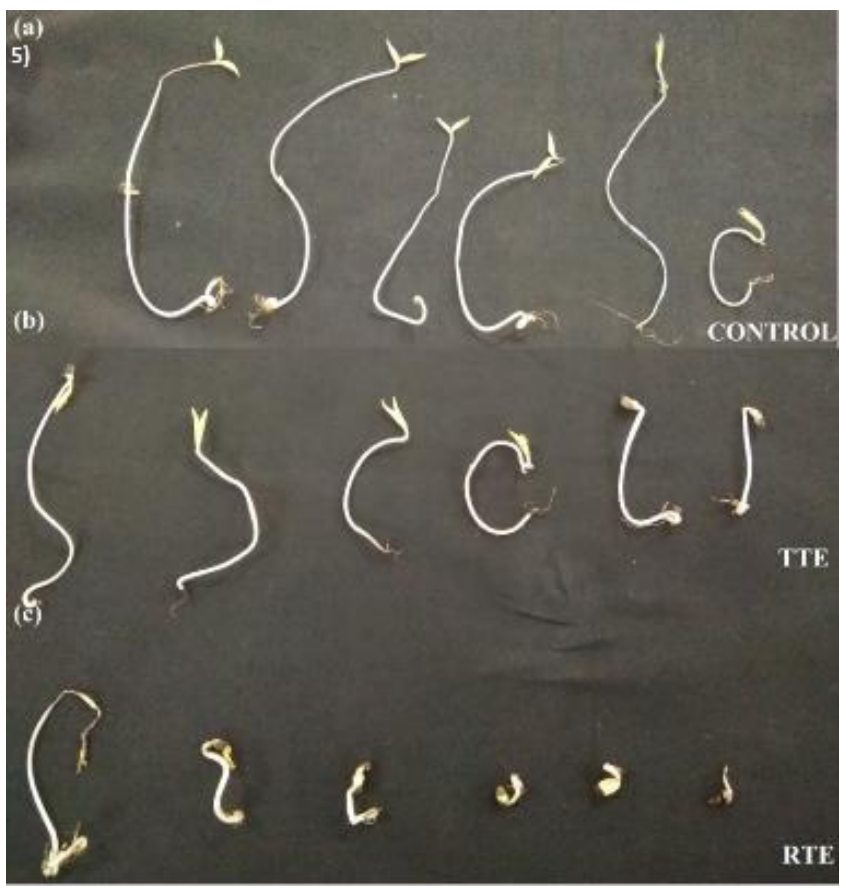

Fig.5 Phytotoxicity analysis of (a) Control (Tap water), (b) Treated textile effluent, (c) Raw textile effluent on $P$. mungo

Table 2 Phytotoxicity study of untreated and treated textile effluent on P. mungo

\begin{tabular}{|l|l|l|l|}
\hline Parameters & Control & Raw textile effluent & Treated textile effluent \\
\hline Germination (\%) & $98 \pm 0.08$ & $33 \pm 0.06$ & $95 \pm 0.03$ \\
\hline Plumule (cm) Mean \pm SD & $6.86 \pm 0.954$ & $0.28 \pm 0.577$ & $0.6 \pm 0.441$ \\
\hline Radicle (cm) Mean \pm SD & $8.38 \pm 2.399$ & $3.15 \pm 1.755$ & $6.46 \pm 1.503$ \\
\hline
\end{tabular}

\subsubsection{Toxicity test with $\mathrm{E}$. coli}

The short-term toxicity of the raw and treated textile effluent was assessed using the well-established bacteria $E$. coli and the results are shown in Fig. 6. The raw textile effluent was highly toxic, while treated textile effluent presented a low toxicity. Fig. 6 shows that after 30 minutes of exposure to raw textile effluent, the number of bacterial cells declined drastically by approximately $41 \%$, indicating acute toxicity to $E$ coli. This was plausibly due to the enormous amount of ionic and acid dyes entering the wastewater during the textile processing. Ionic and disperse dyes discharged from textile processing and dyeing were usually particularly toxic, and some were mutagenic and carcinogenic(Carneiro et al. 2010; Li et al. 2014). On the contrary, it was found that the treated effluent was absolutely harmless to the bacteria, which was evident from their uninhibited growth (cells/ml increased by approximately 10\%). This indicates that the toxicity of textile effluent was reduced to a greater extent after treatment with G. candidum. 


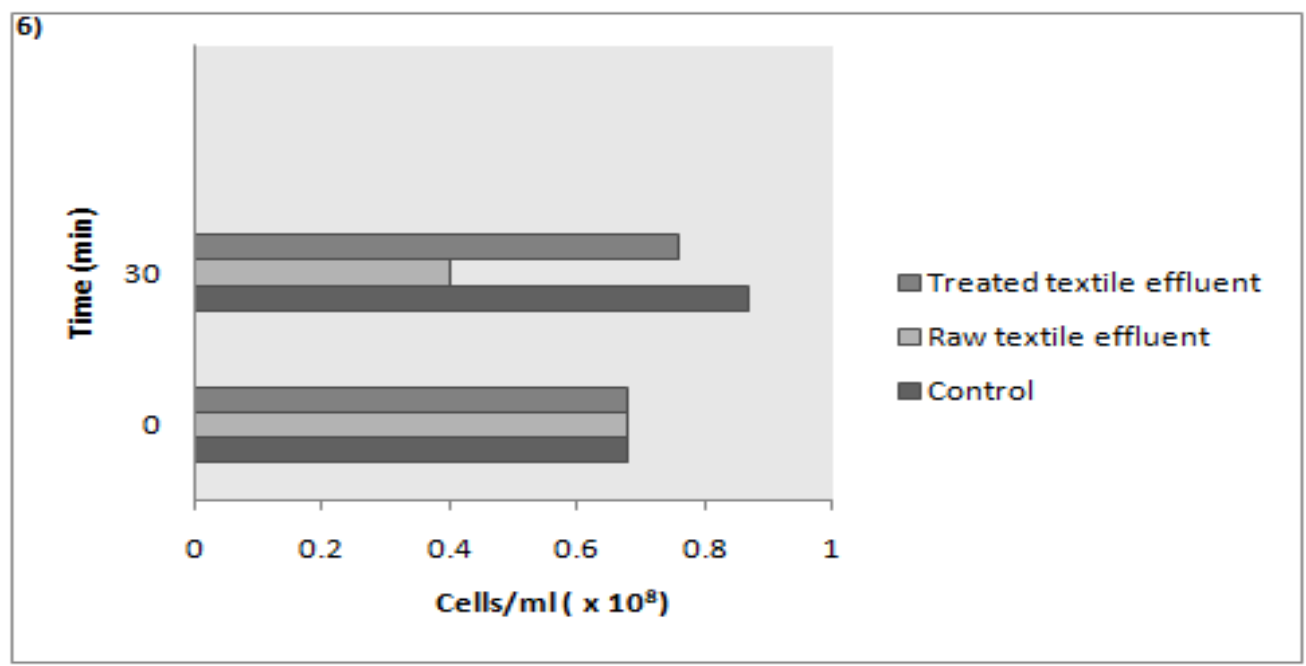

Fig.6 Microbial toxicity analysis of (a) Control (culture medium), (b) Treated textile effluent, (c) Raw textile effluent on E. coli

\subsubsection{Genotoxicity analysis}

The A. cepa study is a standard test to assess the genotoxicity of any toxic substance. The test was carried out to identify MI and chromosomal aberrations in the root cells (Table 3). On the basis of the MI value, (MI value can act as a biosensor for environmental contaminants) the cytotoxic effect of the toxic compound was assessed (Carita and Marin-Morales 2008). Table 3 shows the genotoxic aspects of the textile effluent before and after treatment. The decreased MI value is indicative of decreased cytotoxicity of treated effluent. The textile wastewater typically has a detrimental impact on chromosomal cell division, and this type of aberrations in mitotic cell division is triggered by spindle apparatus proteins malfunctioning (Jadhav et al. 2010) or probably due to decrease in ATP synthesis during cell division. The significant reduction in COD level could then contribute to the decline in the number of aberrant mitotic cells after treatment. The findings recorded were similar to the literature data (Caritá and Marin-Morales 2008; Jadhav et al. 2010).

Table 3 Genotoxicity analysis for the untreated and treated effluent

\begin{tabular}{|l|l|l|}
\hline \multicolumn{1}{|c|}{ Analysis } & Raw Effluent & Treated effluent \\
\hline RL (cm) & $3.28 \pm 0.65$ & $5.84 \pm 0.41$ \\
\hline MI & $0.3 \pm 1.32$ & $0.9 \pm 0.562$ \\
\hline MN & Not found & Not found \\
\hline CB & 3 & 1 \\
\hline TA & 3 & 1 \\
\hline TCA & 50 & 50 \\
\hline Frequency of TA & $0.5 \pm 0.04^{*}$ & $0.25 \pm 0.005$ \\
\hline
\end{tabular}

RL- root length; MI- Mitotic index; MN- micronuclei; CB- Chromosome breaks; TCA- total no. of cells analysed; TA-Total no. of alterations. Values are mean of three experiments, SD(_), significantly different from the control (roots germinated in water), ${ }^{*} \mathrm{P}<0.05,{ }^{* *} \mathrm{P}<0.001$ by one-way analysis of variance (ANOVA) with TukeyeKramer comparison test.

The decrease in colour, COD and BOD might have lead to the minimization in the toxicity of textile effluent. This study indicates that the metabolites produced after biodegradation are less toxic than the compounds present in raw effluent. 


\subsubsection{Relationship between toxicity and COD of raw and treated textile effluent}

Pearson's correlation analysis for the textile effluent indicated a significantly positive correlation between COD and $\mathrm{TU}_{50}\left(\mathrm{r}=0.920, \mathrm{p}<0.05, \mathrm{R}^{2}=0.84\right)$, which suggested that compounds present in the textile effluent were toxic for $E$. coli. However, there was a negative relationship between COD and $\mathrm{TU}_{50}\left(\mathrm{r}=0.088, \mathrm{p}=0.048, \mathrm{R}^{2}=0.77\right)$ in case of treated textile effluent. Similar toxicity and COD correlation studies for textile effluent have been carried out with Vibrio fischeri and Desmodesmus subspicatus. They showed that there was significantly positive correlation between $V$. fischeri and COD; color and $\mathrm{TU}_{50}(\mathrm{r}=0.824,0.57, \mathrm{p}<0.05)$, which suggested that compounds producing color might be toxic for $V$. fischeri. However, there was a negative relationship between $D$. subspicatus and $\mathrm{TU}_{50}$ $(\mathrm{r}=0.625, \mathrm{p}=0.035)$ (Liang et al. 2018).

COD was one of the most widely used water quality monitoring metrics and also was an important measure for the regulation of the usage of wastewater treatment facilities, taxation and surveillance of wastewater effluent (Zheng et al. 2008).Therefore, it was important to establish associations between bio-toxicity and conventional markers such as $\operatorname{COD}$ (Raptis et al. 2014).

\section{Conclusion}

The competent Geotrichum candidum culture involved in the current work biodegraded the toxic textile effluent. The analysis of conventional parameters such as COD, BOD and color were indicative of the decreased toxicity of the treated effluent in comparison to the raw effluent. The effective decolorization and biodegradation of effluent in $18 \mathrm{~h}$ was confirmed by FT-IR and XRD analysis. The plausible biodegradation pathway has been proposed on the basis of metabolites identified by LCMS. This demonstrated the first report on the proposed pathway for enzymatic degradation study of acid orange 10 by $G$. candidum. The genotoxicity, phytotoxicity and microbial toxicity analyses proved the raw effluent is harmful, whereas the treated effluent is less toxic. Relationship between effluent $\mathrm{COD}$ and $\mathrm{TU}_{50}$ showed that an increase in effluent $\mathrm{COD}$ resulted in increase in wastewater toxicity. There was a clearly defined correlation between toxicity and COD. It was evident that toxic effects of the textile effluent were significantly reduced upon treatment with $G$. candidum. The major relationships between toxicity and COD will provide directions for more efficient control of textile dyeing effluents. This is the first report on the positive correlation between toxicity and COD of textile effluent using G. candidum within a very short stretch of time (18h). Therefore, the findings of this study have shown that the treated effluent was safer to be released in regard to physicochemical parameters and toxicity unit $\left(\mathrm{TU}_{50}\right)$. The correlation between conventional indicators and toxicity may provide assistance in effluent management.

\section{References}

Agrawal K, Verma P (2019) Biodegradation of synthetic dye Alizarin Cyanine Green by yellow laccase producing strain Stropharia sp. ITCC-8422. Biocatal Agric Biotechnol 21:101291. https://doi.org/10.1016/j.bcab.2019.101291

Alexander B, Browse DJ, Reading SJ, Benjamin IS (1999) A simple and accurate mathematical method for calculation of the EC50. J Pharmacol Toxicol Methods 41:55-58. https://doi.org/10.1016/S10568719(98)00038-0

Bankole PO, Adekunle AA, Obidi OF, et al (2018) Biodegradation and detoxification of Scarlet RR dye by a newly isolated filamentous fungus, Peyronellaea prosopidis. Sustain Environ Res 28:214-222. https://doi.org/10.1016/j.serj.2018.03.001

Bayram TT, Nuhoğlu A, Aladağ E (2017) Investigation of biodegradation and growth kinetics of dairy wastewater in a batch reactor. Bulg Chem Commun 49:896 - 900

Caritá R, Marin-Morales MA (2008) Induction of chromosome aberrations in the Allium cepa test system caused by the exposure of seeds to industrial effluents contaminated with azo dyes. Chemosphere 72:722-725. 
https://doi.org/10.1016/j.chemosphere.2008.03.056

Carneiro PA, Umbuzeiro GA, Oliveira DP, Zanoni MVB (2010) Assessment of water contamination caused by a mutagenic textile effluent/dyehouse effluent bearing disperse dyes. J Hazard Mater 174:694-699. https://doi.org/10.1016/j.jhazmat.2009.09.106

Chacko JT, Subramaniam K (2011) Enzymatic Degradation of Azo Dyes - A Review. Int J Environ Sci 1:1250-60

Chen K-C, Wu J-Y, Liou D-J, Hwang S-CJ (2003) Decolorization of the textile dyes by newly isolated bacterial strains. J Biotechnol 101:57-68. https://doi.org/10.1016/S0168-1656(02)00303-6

Davies LC, Pedro IS, Novais JM, Martins-Dias S (2006) Aerobic degradation of acid orange 7 in a vertical-flow constructed wetland. Water Res 40:2055-2063. https://doi.org/10.1016/j.watres.2006.03.010

E.W. Rice, R.B. Baird, A.D. Eaton E (2017) APHA Standard Methods For The Examination Of Water And Wastewater, 23rd ed. American Public Health Association, American Water Works Association, Water Environment Federation, Washington DC.

Gurbuz F, Ozcan A, Ciftci H, et al (2019) Treatment of textile effluents through bio-composite column: decolorization and COD reduction. Int J Environ Sci Technol 16:8653-8662. https://doi.org/10.1007/s13762019-02430-3

Huber W, Koella JC (1993) A comparison of three methods of estimating EC50 in studies of drug resistance of malaria parasites. Acta Trop 55:257-261. https://doi.org/10.1016/0001-706X(93)90083-N

Jadhav JP, Kalyani DC, Telke AA, et al (2010) Evaluation of the efficacy of a bacterial consortium for the removal of color, reduction of heavy metals, and toxicity from textile dye effluent. Bioresour Technol 101:165-173. https://doi.org/10.1016/j.biortech.2009.08.027

Kim SJ, Shoda M (1999) Decolorization of molasses and a dye by a newly isolated strain of the fungusGeotrichum candidum Dec 1. Biotechnol Bioeng 62:114-119. https://doi.org/10.1002/(SICI)10970290(19990105)62:1<114::AID-BIT13>3.0.CO;2-T

Kumar V, Singh S, Kashyap N, et al (2015a) Bioremediation of heavy metals by employing resistant microbial isolates from agricultural soil irrigated with Industrial Waste water. Orient J Chem 31:357-361. https://doi.org/10.13005/ojc/310142

Kumar V, Singh S, Manhas A, et al (2014) Bioremediation of Petroleum hydrocarbon by using Pseudomonas species isolated from Petroleum contaminated soil. Orient J Chem 30:1771-1776. https://doi.org/10.13005/ojc/300436

Kumar V, Singh S, Singh J, Upadhyay N (2015b) Potential of Plant Growth Promoting Traits by Bacteria Isolated from Heavy Metal Contaminated Soils. Bull Environ Contam Toxicol 94:807-814. https://doi.org/10.1007/s00128-015-1523-7

Kumar V, Singh S, Singh R, et al (2017) Design, synthesis, and characterization of 2,2-bis(2,4-dinitrophenyl)-2(phosphonatomethylamino)acetate as a herbicidal and biological active agent. J Chem Biol 10:179-190. https://doi.org/10.1007/s12154-017-0174-z

Kumar V, Upadhyay N, Singh S, et al (2013) Thin-Layer Chromatography: Comparative Estimation of Soil's Atrazine. Curr World Environ J 8:469-472. https://doi.org/10.12944/CWE.8.3.17

Lee SS, Bai H, Liu Z, Sun DD (2013) Novel-structured electrospun TiO2/CuO composite nanofibers for high efficient photocatalytic cogeneration of clean water and energy from dye wastewater. Water Res 47:40594073. https://doi.org/10.1016/j.watres.2012.12.044

Li J, Shao Z, Chen C, Wang X (2014) Hierarchical GOs/Fe 3 O 4 /PANI magnetic composites as adsorbent for ionic dye pollution treatment. RSC Adv 4:38192. https://doi.org/10.1039/C4RA05800C

Liang J, Ning X, Sun J, et al (2018) Toxicity evaluation of textile dyeing effluent and its possible relationship with chemical oxygen demand. Ecotoxicol Environ Saf 166:56-62. https://doi.org/10.1016/j.ecoenv.2018.08.106

Ma K, Qin Z, Zhao Z, et al (2016) Toxicity evaluation of wastewater collected at different treatment stages from a pharmaceutical industrial park wastewater treatment plant. Chemosphere 158:163-170. https://doi.org/10.1016/j.chemosphere.2016.05.052

Mahata A, Rai RK, Choudhuri I, et al (2014) Direct vs. indirect pathway for nitrobenzene reduction reaction on a Ni catalyst surface: a density functional study. Phys Chem Chem Phys 16:26365-26374. 
https://doi.org/10.1039/C4CP04355C

Maljaei A, Arami M, Mahmoodi NM (2009) Decolorization and aromatic ring degradation of colored textile wastewater using indirect electrochemical oxidation method. Desalination 249:1074-1078. https://doi.org/10.1016/j.desal.2009.05.016

Mishra V, Gupta A, Kaur P, et al (2016) Synergistic effects of Arbuscular mycorrhizal fungi and plant growth promoting rhizobacteria in bioremediation of iron contaminated soils. Int J Phytoremediation 18:697-703. https://doi.org/10.1080/15226514.2015.1131231

R. Hamidi M, Jovanova B, Kadifkova Panovska T (2014) Toxicological evaluation of the plant products using Brine Shrimp (Artemia salina L.) model. Maced Pharm Bull 60:9-18. https://doi.org/10.33320/maced.pharm.bull.2014.60.01.002

Rajhans, G., Barik. A.,Sen, S.K. and Raut S (2019) Immobilized white rot fungal consortium: An innovative and green technology for textile effluent treatment. In: 60th Annual conference of association of microbiologists of India (AMI-2019) \& International symposium on microbial technologies in sustainable development of energy, environment, agriculture and health. Central University of Haryana. Haryana, p 175

Rajhans G, Kumar Sen S, Barik A, Raut S (2020a) De-colorization of textile effluent using immobilized Geotrichum candidum : An insight into mycoremediation. Lett Appl Microbiol lam.13430. https://doi.org/10.1111/lam.13430

Rajhans G, Sen SK, Barik A, Raut S (2020b) Elucidation of fungal dye-decolourizing peroxidase (DyP) and ligninolytic enzyme activities in decolourization and mineralization of azo dyes. J Appl Microbiol 129:16331643. https://doi.org/10.1111/jam.14731

Raptis CE, Juraske R, Hellweg S (2014) Investigating the relationship between toxicity and organic sum-parameters in kraft mill effluents. Water Res 66:180-189. https://doi.org/10.1016/j.watres.2014.08.023

Reddy S, Osborne JW (2020) Biodegradation and biosorption of Reactive Red 120 dye by immobilized Pseudomonas guariconensis: Kinetic and toxicity study. Water Environ Res 92:1230-1241. https://doi.org/10.1002/wer.1319

Sen SK, Patra P, Das CR, et al (2019) Pilot-scale evaluation of bio-decolorization and biodegradation of reactive textile wastewater: An impact on its use in irrigation of wheat crop. Water Resour Ind 21:100106. https://doi.org/10.1016/j.wri.2019.100106

SeongJun Kim; Makoto Shoda (1998) Decolorization of molasses by a new isolate of Geotrichum candidum in a jar fermenter. Biotechnol Tech 12:497-499. https://doi.org/10.1023/a:1008824119174

Shintani N, Shoda M (2013) Decolorization of oxygen-delignified bleaching effluent and biobleaching of oxygendelignified kraft pulp by non-white-rot fungus Geotrichum candidum Dec 1. J Environ Sci 25:S164-S168. https://doi.org/10.1016/S1001-0742(14)60649-5

Singh N, Balomajumder C (2016) Simultaneous biosorption and bioaccumulation of phenol and cyanide using coconut shell activated carbon immobilized Pseudomonas putida (MTCC 1194). J Environ Chem Eng 4:16041614. https://doi.org/10.1016/j.jece.2016.02.011

Singh S, Kumar V, Chauhan A, et al (2018) Toxicity, degradation and analysis of the herbicide atrazine. Environ Chem Lett 16:211-237. https://doi.org/10.1007/s10311-017-0665-8

Singh S, Kumar V, Upadhyay N, et al (2017) Efficient biodegradation of acephate by Pseudomonas pseudoalcaligenes PS-5 in the presence and absence of heavy metal ions [Cu(II) and Fe(III)], and humic acid. 3 Biotech 7:262. https://doi.org/10.1007/s13205-017-0900-9

Sprague JB (1970) Measurement of pollutant toxicity to fish. II. Utilizing and applying bioassay results. Water Res 4:3-32. https://doi.org/10.1016/0043-1354(70)90018-7

Teresa J Norberg-King (1993) A linear interpolation method for sublethal toxicity: The inhibition concentration (ICp) approach (version 2.0). National Effluent Toxicity Assessment Center (NETAC) Technical Report, USEPA, Duluth, MN

Vijayalakshmidevi SR, Muthukumar K (2015) Improved biodegradation of textile dye effluent by coculture. Ecotoxicol Environ Saf 114:23-30. https://doi.org/10.1016/j.ecoenv.2014.09.039

Wanderley CRP, Andrade MV, Pereira LJ, et al (2018) Azo Dye Mineralization by Phanerochaete Chysosporium in 
a Sequencing Bath Reactor. Brazilian Arch Biol Technol 61:. https://doi.org/10.1590/1678-4324-2018180195 Periploca sepium and Its Main Component 2-Hydroxy-4-methoxybenzaldehyde. Molecules 15:5807-5817. https://doi.org/10.3390/molecules15085807

Yaseen DA, Scholz M (2016) Shallow pond systems planted with Lemna minor treating azo dyes. Ecol Eng 94:295305. https://doi.org/10.1016/j.ecoleng.2016.05.081

Yin, L., Chen, Z.-H \& Zhao S-J (2008) Optimization of laccase production from Geotrichum candidum and decoloration of azo dyes by laccase. 36:85-90

Yu, W., Liu, W., Huang, H., Zheng, F., Wang, X., Wu, Y., ... Jin Y (2014) Application of a Novel Alkali-Tolerant Thermostable DyP-Type Peroxidase from Saccharomonospora viridis DSM 43017 in Biobleaching of Eucalyptus Kraft Pulp. PLoS One 9:110319. https://doi.org/10.1371/journal.pone.0110319 Chemical Oxygen Demand. Adv Mater 20:1044-1049. https://doi.org/10.1002/adma.200701619 
Figures

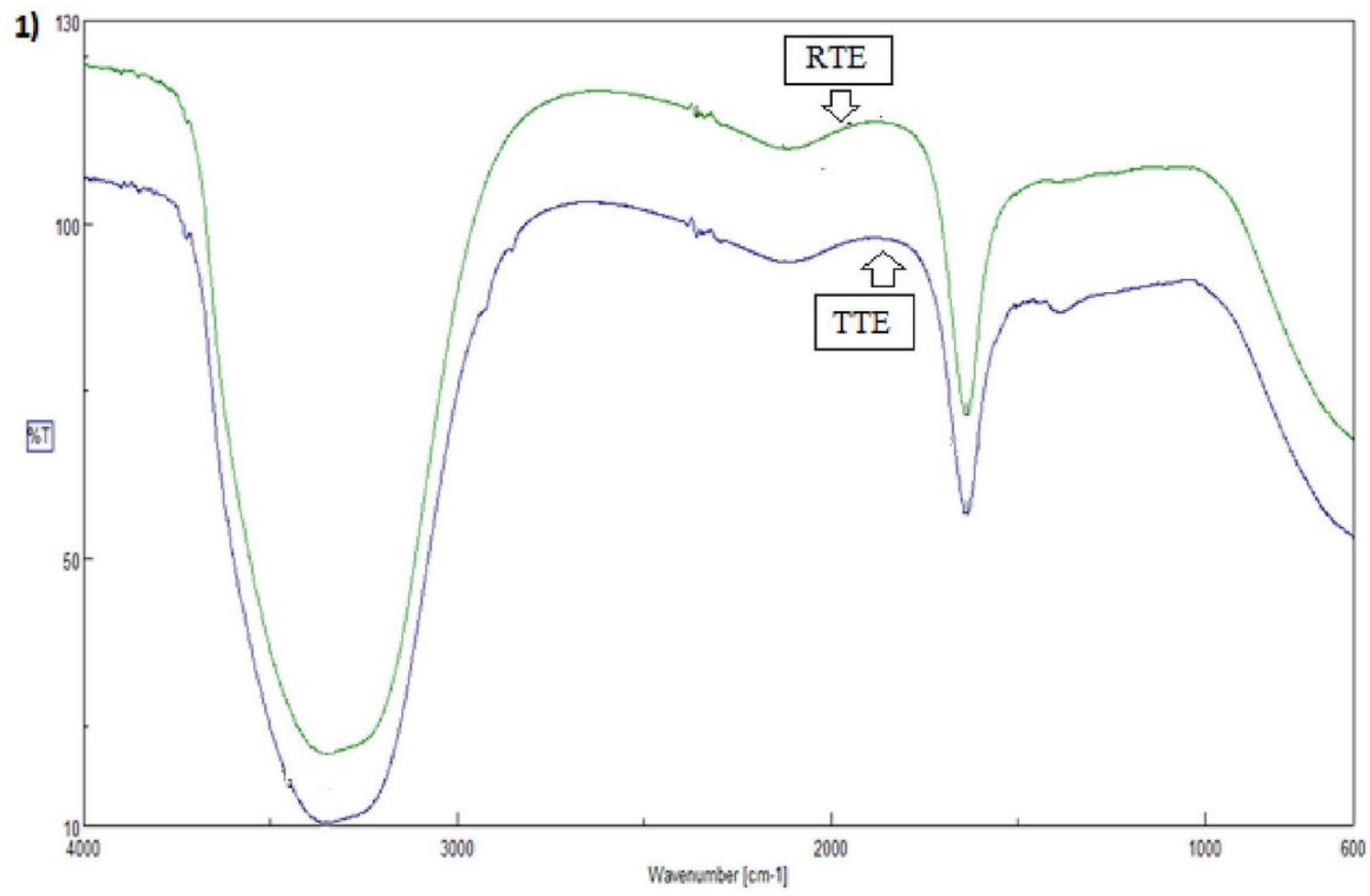

Figure 1

FT-IR spectral analyses of raw and treated textile effluent 

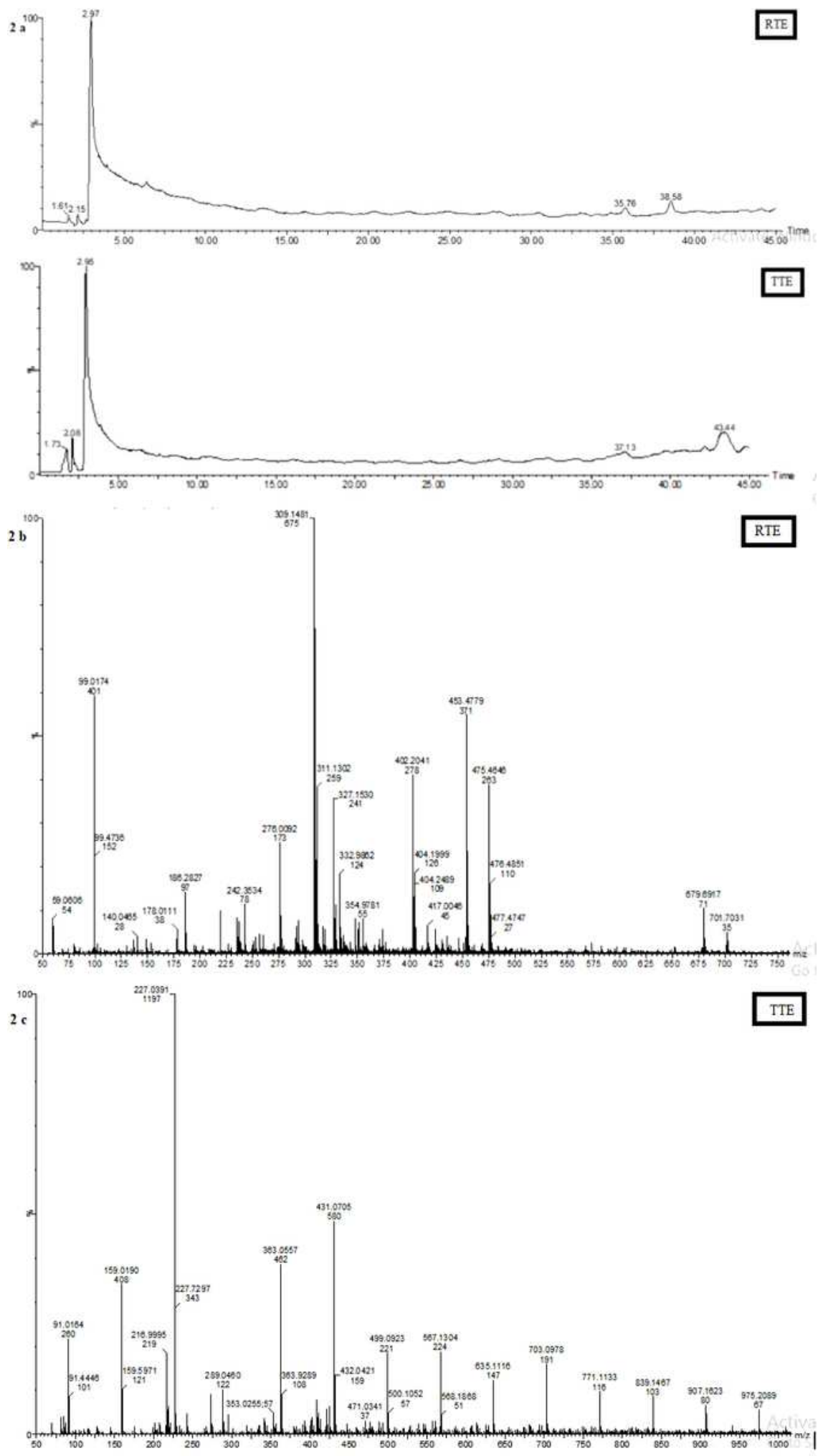

Figure 2

LC-MS analysis of raw and treated textile effluent 

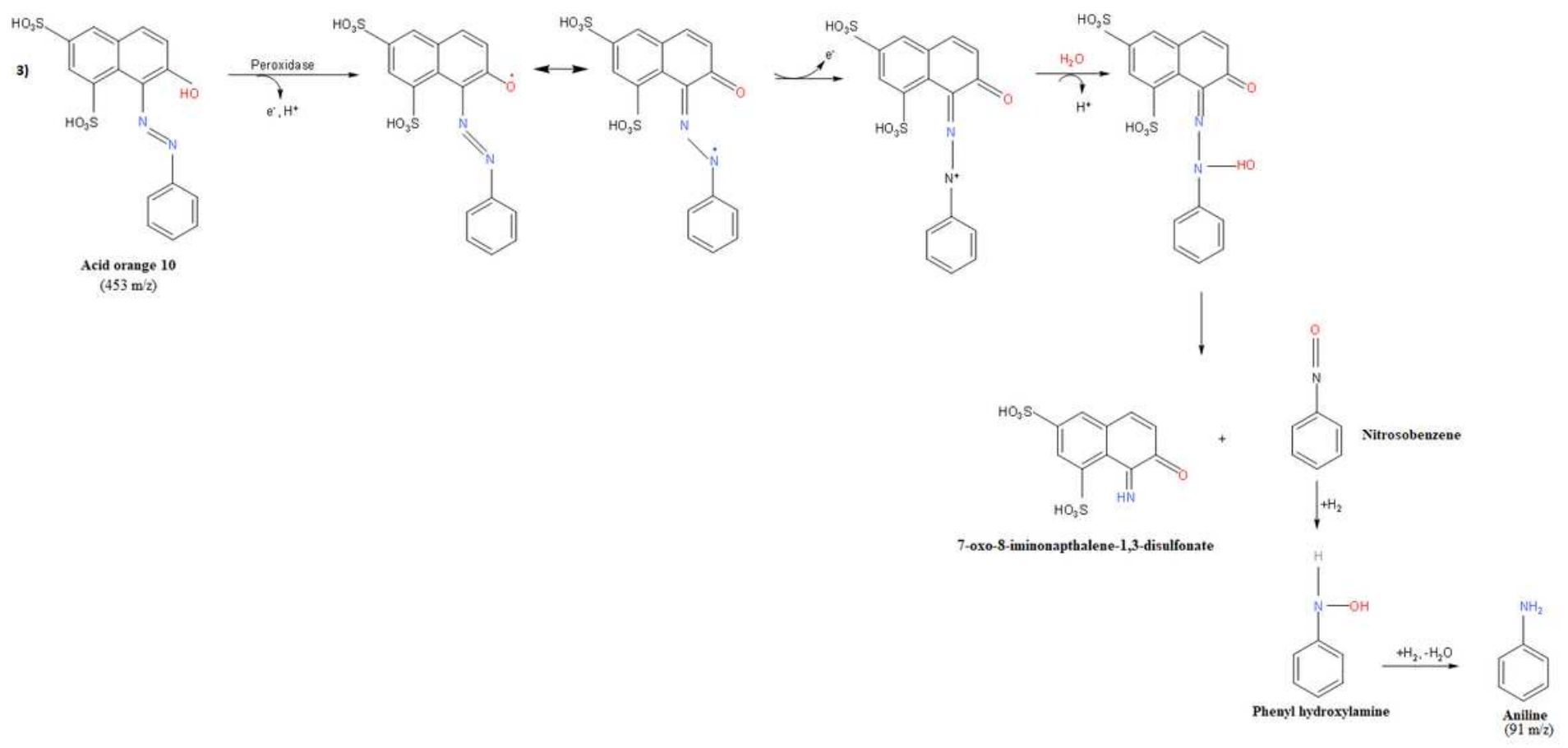

Figure 3

Proposed pathway for degradation of acid orange 10 dye by G. candidum

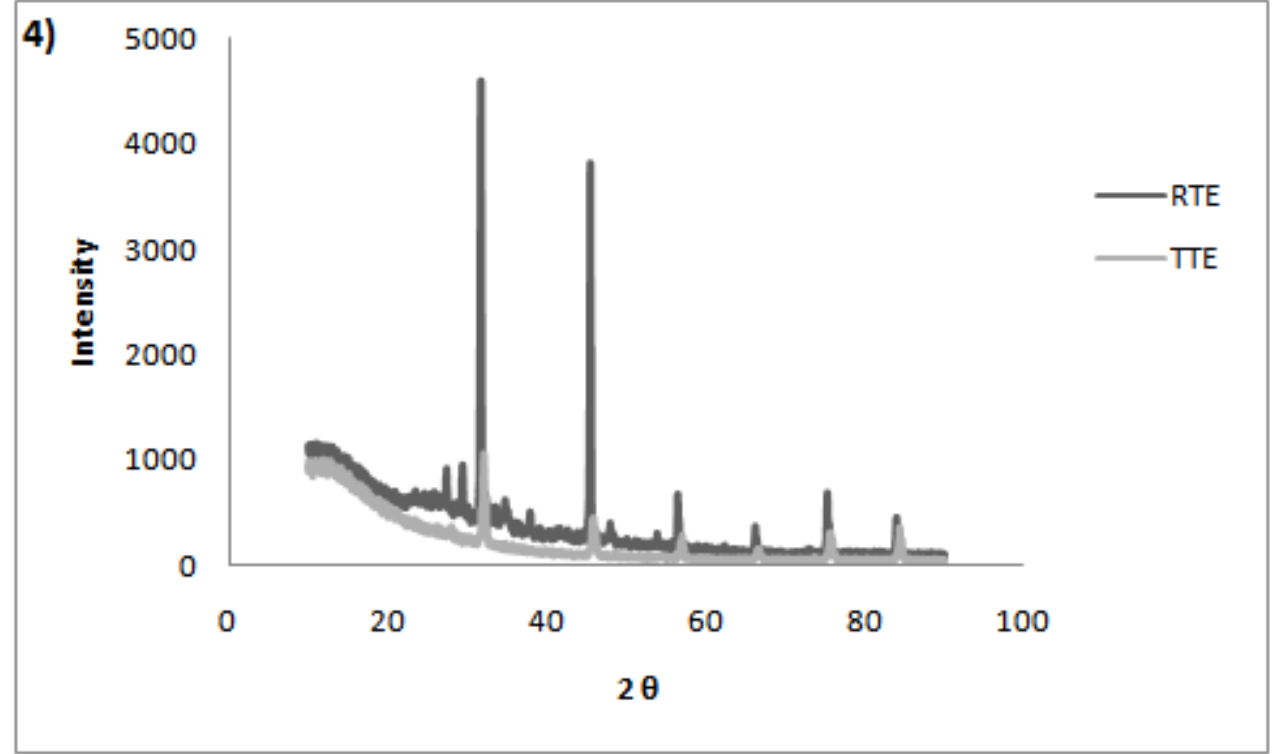

Figure 4

X-ray diffraction pattern of raw and treated textile effluent 


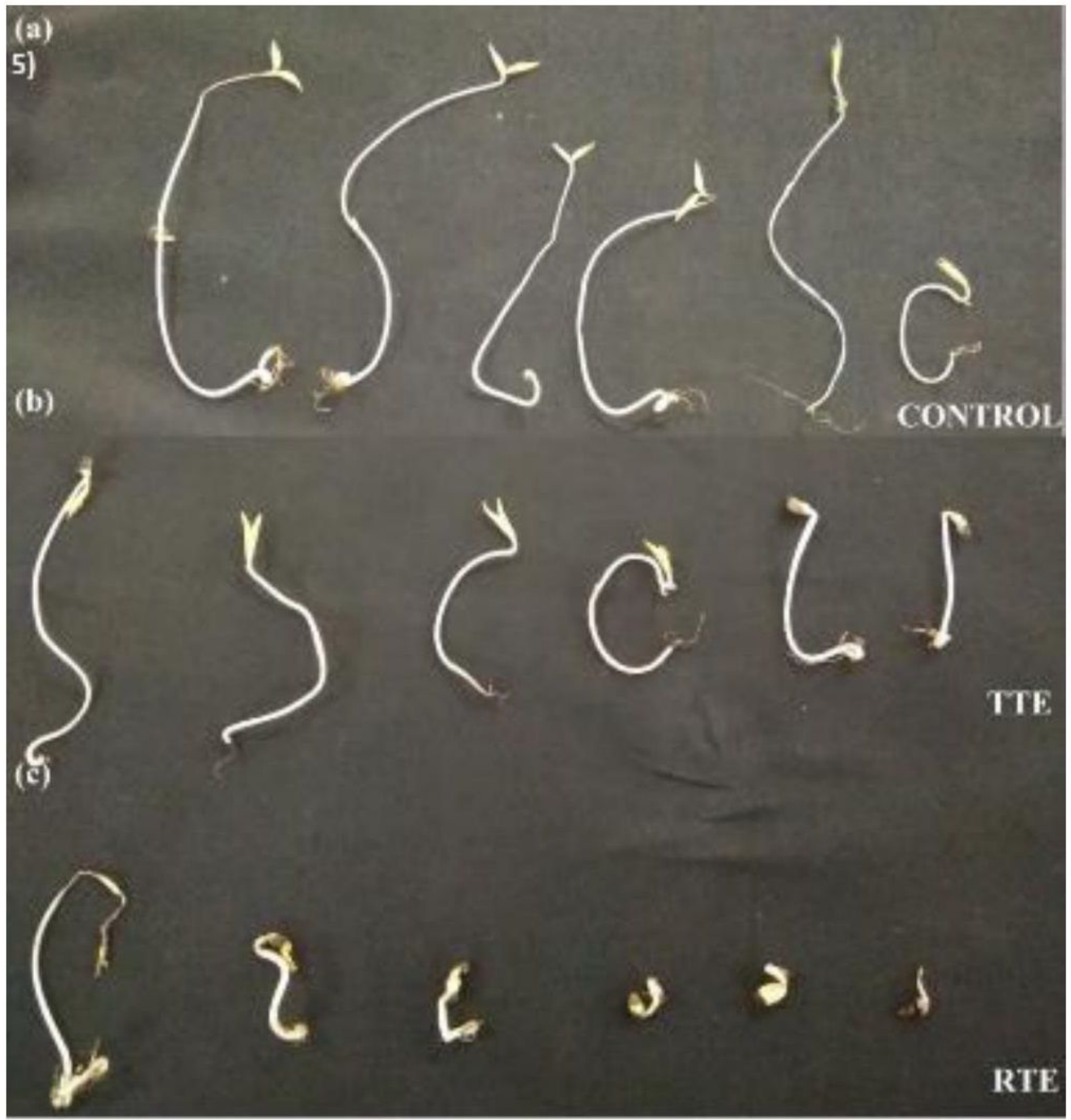

Figure 5

Phytotoxicity analysis of (a) Control (Tap water), (b) Treated textile effluent, (c) Raw textile effluent on P. mungo 
6)

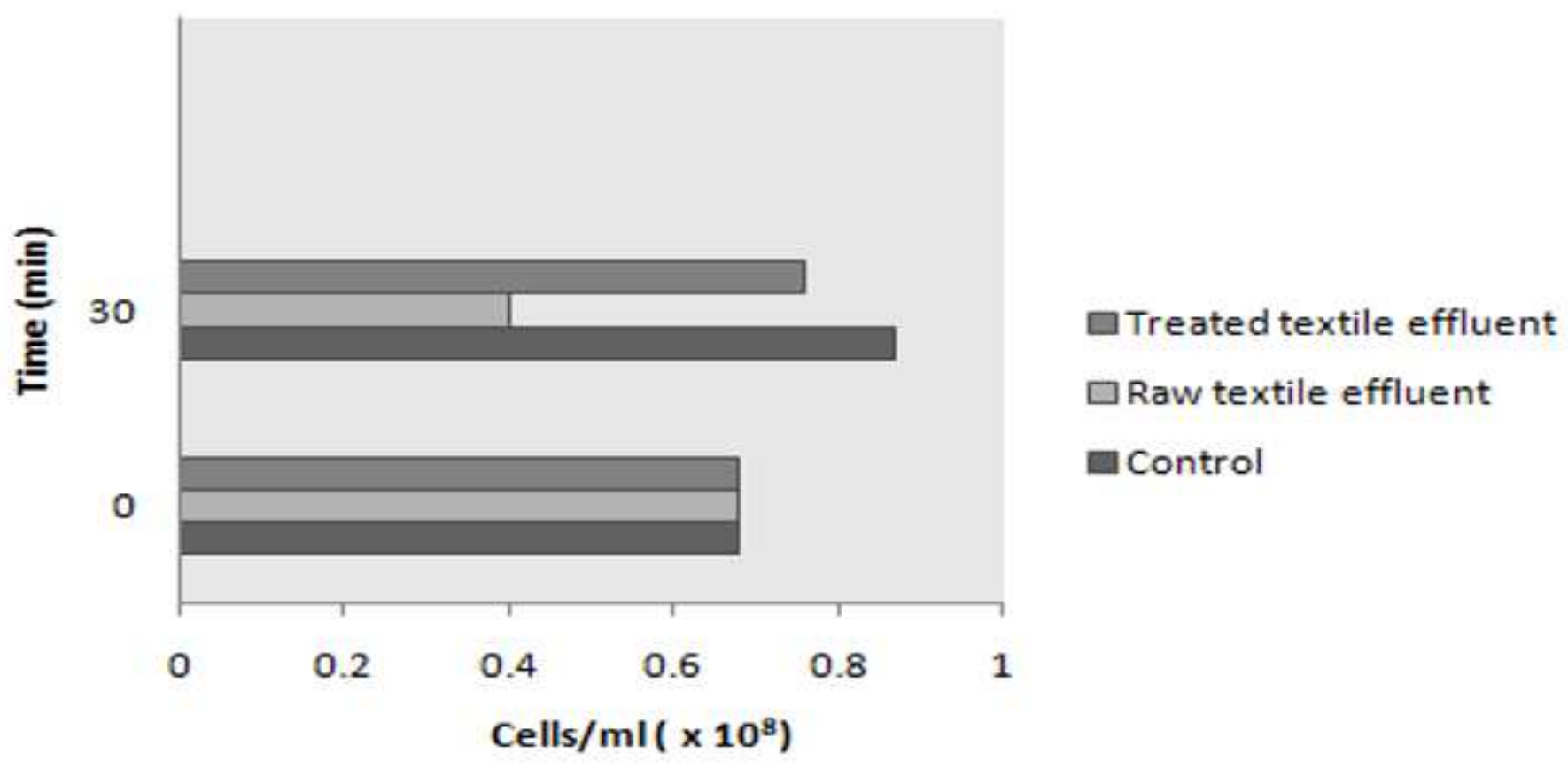

Figure 6

Microbial toxicity analysis of (a) Control (culture medium), (b) Treated textile effluent, (c) Raw textile effluent on E. coli 